\title{
A Comparative Study of Plain and Hyperbaric Solution of Ropivacaine for Spinal Anaesthesia in Minor Gynaecological and Urological Surgeries
}

\author{
Irfan Waris ${ }^{1}$, Imran Khan KD \\ ${ }^{1}$ Assistant Professor, Department of Anesthesiiology, KBNIMS, Kalaburgi, Karnataka, ${ }^{2}$ Chief Anesthesiologist and Intensivist, IQRA Hospital, Gokak, \\ Karnataka.
}

\section{Abstract}

Background: To compare the clinical effects of $3 \mathrm{ml}$ of intrathecal hyperbaric ropivacaine $0.5 \%$ ( $2 \mathrm{ml}$ of $0.75 \%$ plain ropivacaine and $1 \mathrm{ml}$ of $25 \%$ dextrose) with $3 \mathrm{ml}$ of $0.5 \%$ plain ropivacaine ( $2 \mathrm{ml}$ of $0.75 \%$ plain ropivacaine and $1 \mathrm{ml}$ of $0.9 \%$ normal saline) for spinal anaesthesia in minor gynaecological and urological surgeries. Subjects and Methods: 60 patients belonging to ASA physical status I \& II scheduled for minor gynaecological and urological surgeries under spinal anaesthesia were randomly selected for the study and are divided into two groups of 30 each. Group $\mathrm{H}$ patients received $3 \mathrm{ml}$ of intrathecal hyperbaric ropivacaine $0.5 \%$ ( $2 \mathrm{ml}$ of $0.75 \%$ plain ropivacaine and $1 \mathrm{ml}$ of $25 \%$ dextrose). Group P patients received $3 \mathrm{ml}$ of plain ropivacaine $0.5 \%$ ( $2 \mathrm{ml}$ of $0.75 \%$ plain ropivacaine and $1 \mathrm{ml}$ of $0.9 \%$ saline). Results: There was significant difference between the two groups in mean time to onset of sensory block at T10, $257.5 \pm 23.03$ sec with group $\mathrm{H}$ and $478.0 \pm$ $16.48 \mathrm{sec}$ with group $\mathrm{P},(\mathrm{P}<0.0001)$. Total duration of sensory block was $201.7 \pm 8.64 \mathrm{~min}$ in group $\mathrm{H}$ and $261.17 \pm 8.27$ min in group $\mathrm{P}$, which is significant $(\mathrm{P}<0.0001)$.Mean time of onset of motor block was $355.50 \pm 16.83 \mathrm{sec}$ in group $\mathrm{H}$ and $568.33 \pm 2.76$ sec in group $\mathrm{P}$, which is significant $(\mathrm{P}<0.0001)$. Duration of motor block was $127.33 \pm 6.53 \mathrm{~min}$ in group $\mathrm{H}$ and $168.83 \pm 8.27$ min in group $\mathrm{P}$ which is clinically and statistically significant $(\mathrm{P}<0.0001)$. Hemodynamic parameters were comparable in both groups. Conclusion: Addition of glucose to plain ropivacaine increases the speed of onset of both sensory and motor block, and also increases the speed of recovery from sensory and motor block in minor gynaecological and urological surgeries. Plain solutions are less reliable for surgery above a dermatomal level of T10.

Keywords: Ropivacaine, Spinal Anaesthesia, Urological Surgeries.

Corresponding Author: Dr. Imran Khan KD, Chief Anesthesiologist and Intensivist, IQRA Hospital, Gokak, Karnataka.

Received: July 2019

Accepted: July 2019

\section{Introduction}

Day care surgery demands the highest standards of professional skills and organization. Although, the operations could be minor, an anaesthetic is never minor. Day care surgery has now become an accepted method of treatment for a number of surgical patients. Preliminary work has shown that ropivacaine provides spinal anaesthesia of shorter duration than bupivacaine, and may be of particular use in the day-care setting. ${ }^{[1]}$ However, there are few data comparing the actions of plain and hyperbaric solutions of this drug. The disadvantages of spinal anaesthesia with lidocaine and bupivaciane include hypotension and its associated intraoperative nausea and vomiting. There are clinical reports about bupivacaine related cardiac toxicity, like ventricular dysrythmias. Therefore, a newer drug was always in need to avoid the bupivacaine related toxicity, at the same time, to have more favorable results than the conventional drug, bupivacaine in day care surgeries. ${ }^{[2,3]}$ Ropivacaine is a relatively new amino amide long acting enantiomerically pure(s-enantiomer) local anaesthetic with high pka and low lipid solubility, and it is considered to block sensory nerves to greater degree than motor nerves and having similar local anaesthetic properties and chemical structure to that of bupivacaine. Ropivacaine being comparatively less cardio toxic1, also produces minimal motor blockade of shorter duration2 which relieves the psychological distress of being immobile for a longer period of time and helps early mobilization postoperatively. ${ }^{[4]}$

The current study was designed to compare the plain and hyperbaric solution of ropivacaine for spinal anaesthesia in minor gynaecological and urological surgeries and their usefulness in day care setting.

\section{Subjects and Methods}

The study protocol was approved by Hospital Ethics committee and Ethical clearance was obtained from the institution for the study. Preanaesthetic check up was done one day prior to the surgery. Patients were evaluated for any systemic diseases and laboratory investigations recorded. The procedure of spinal anesthesia was explained to the patients and written consent was obtained. 
Patients advised minimum period of fasting and premedicated with inj $10 \mathrm{mg}$ metaclopramide and $50 \mathrm{mg}$ ranitidine in preoperative holding. Patient was preloaded with an iv infusion of $500 \mathrm{ml}$ of ringer lactate.

Sixty patients were randomly divided into two groups of thirty each.

Group P: Thirty patients received $3 \mathrm{ml}$ of injection $0.5 \%$ plain ropivacaine $(2 \mathrm{ml}$ of $0.75 \%$ plain ropivacaine and $1 \mathrm{ml}$ of $0.9 \%$ normal saline) intrathecally. solution was prepared aseptically immediately before injection.

Group H: Thirty patients received $3 \mathrm{ml}$ of $0.5 \%$ hyperbaric ropivacaine ( $2 \mathrm{ml}$ of $0.75 \%$ plain ropivacaine and $1 \mathrm{ml}$ of $25 \%$ dextrose) intrathecally. hyperbaric ropivacaine was aseptically prepared immediately before the injection.

\section{Preparation of OR}

Boyle's anesthesia machine with all resuscitative equipments was kept ready before the procedure.

After shifting to the operating theatre, iv access was obtained on the forearm with 18 gauge iv cannula and iv infusion started with Ringer Lactate.

Patients were monitored for heart rate (HR), non invasive blood pressure (NIBP), oxygen saturation ( $\mathrm{SpO} 2)$. Spinal anesthesia was performed with the patient in the lateral position using a 25-gauge Quincke needle at the L3-4 interspace. The spinal analgesic solution was administered in optimum period. Patient was turned gently and placed supine.

After the spinal block, $\mathrm{HR}, \mathrm{SpO} 2$ and NIBP were measured every 5, 10,15 20,30 minute. Hypotension was defined as $20 \%$ decrease in blood pressure from baseline values, and was treated with incremental iv boluses of Inj. mephenteramine $6 \mathrm{mg}$. Bradycardia was defined as heart rate less than $60 \mathrm{bpm}$ and treated with iv atropine $0.6 \mathrm{mg}$.

The following variables were recorded. Haemodynamic parameters, and Time for onset of sensory block at T10, level of sensory block achieved, total duration of sensory block, time of onset of motor block, total duration of motor block.

\section{Assessment of Sensory Blockade:}

The onset of sensory block was tested by pin-prick method using a hypodermic needle. The time of onset was taken from the time of injection of drug into subarachnoid space to loss of pin prick sensation at T10. The duration of sensory blockade was taken as time from onset to time of return of pinprick sensation to S1 (heel) dermatomal area.

\section{Assessment of Motor Blockade:}

Motor block was assessed was by Modified Bromage scale. The time interval between injections of drug into subarachnoid space, to the patient's inability to lift the straight extended leg was taken as onset time (bromage 1). The duration of motor block was taken from time of injection to complete regression of motor block (ability to lift the extended leg). (Modified Bromage scale: $0=$ full leg movement; $1=$ inability to raise extended leg, can bend knee; $2=$ inability to bend knee, can flex ankle; $3=$ no movement).

\section{Statistical Analysis:}

Data were expressed in mean $\pm \mathrm{SD}$. Comparison between groups was done using student's t-test for quantitative data and for qualitative data, chi-square test was used. Results were considered statistically significant for $p$ values $<0.05$. Data were analyzed using software SPSS v16.0

\section{Results}

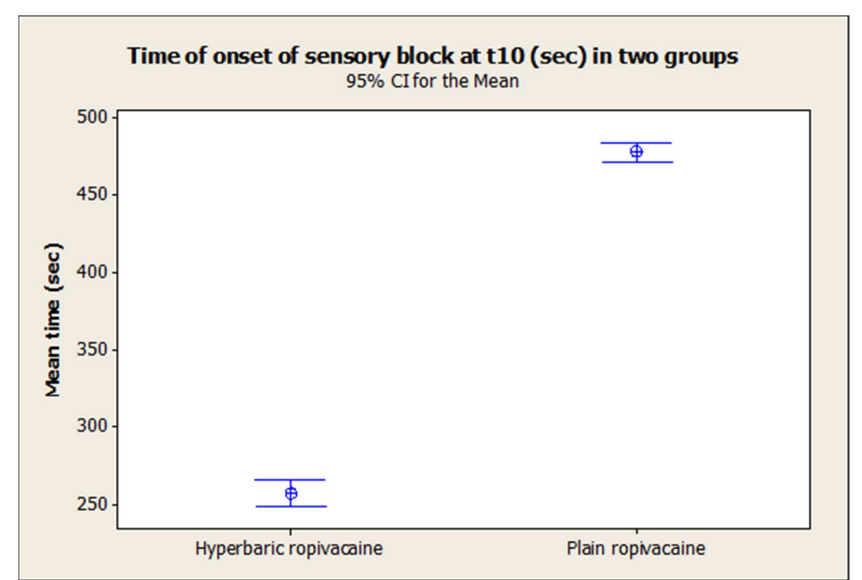

Figure 1: Time of Onset of sensory block at T10

In group $\mathrm{H}$, mean duration of onset of sensory blockade was $257.5 \pm 23.03$ seconds, whereas in group $\mathrm{P}$, mean duration of onset of sensory blockade was $478.0 \pm 16.48$ seconds. The difference between the groups was statistically highly significant $(\mathrm{P}<0.001)$. Hence, showing that there was faster onset of sensory block in group $\mathrm{H}$

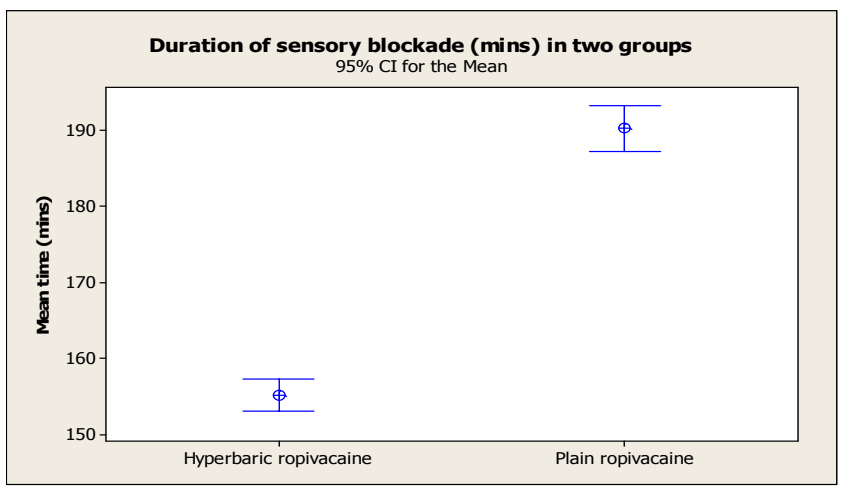

Figure 2: Duration of sensory blockade

In group $\mathrm{H}$, mean duration of sensory blockade was $201.7 \pm$ 8.64 mins, whereas in group $\mathrm{P}$, mean duration of sensory blockade was $261.17 \pm 8.27$ mins. The difference between the groups was statistically highly significant $(\mathrm{P}<0.001)$.Hence, showing that there was early recovery from sensory blockade in group $\mathrm{H}$.

Table 1: Comparison of sensory block level in between two group

\begin{tabular}{|l|l|l|}
\hline $\begin{array}{l}\text { Sensory Block } \\
\text { Level }\end{array}$ & $\begin{array}{l}\text { Hyperbaric } \\
\text { ropivacaine (\%) }\end{array}$ & Plain ropivacaine (\%) \\
\hline T6 & $17(57)$ & 0 \\
\hline T8 & $11(37)$ & $8(27)$ \\
\hline T9 & 0 & $3(10)$ \\
\hline T10 & $2(6)$ & $19(63)$ \\
\hline
\end{tabular}

In group $\mathrm{H} 94 \%$ of patients achieved sensory block level above T10, whereas In group P only $37 \%$ patients achieved sensory block level above T10, Hence plain ropivacaine is less reliable for surgeries above the level of T10. 


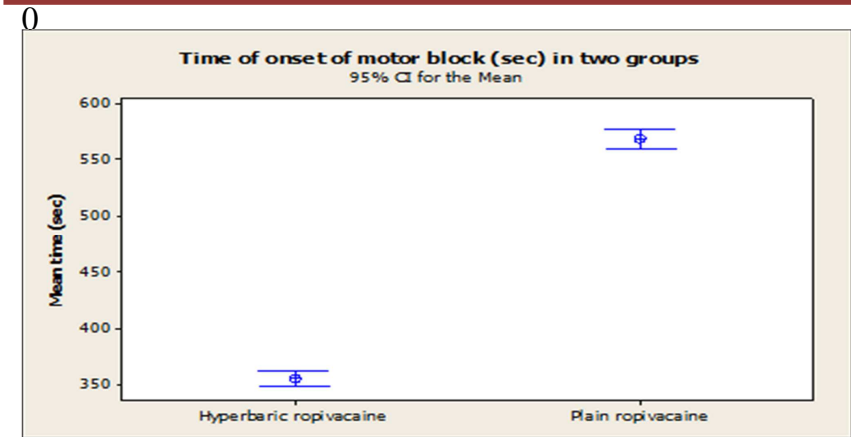

Figure 3: Time of onset of motor blockade (sec) in two groups

In group $\mathrm{H}$, mean duration of onset of motor blockade was $355.50 \pm 16.83$ seconds, whereas in group $\mathrm{P}$, mean duration of onset of motor blockade was $568.33 \pm 2.76$ seconds. The difference between the groups was statistically highly significant $(\mathrm{P}<0.001)$. Hence, showing that there was faster onset of motor block in group $\mathrm{H}$.

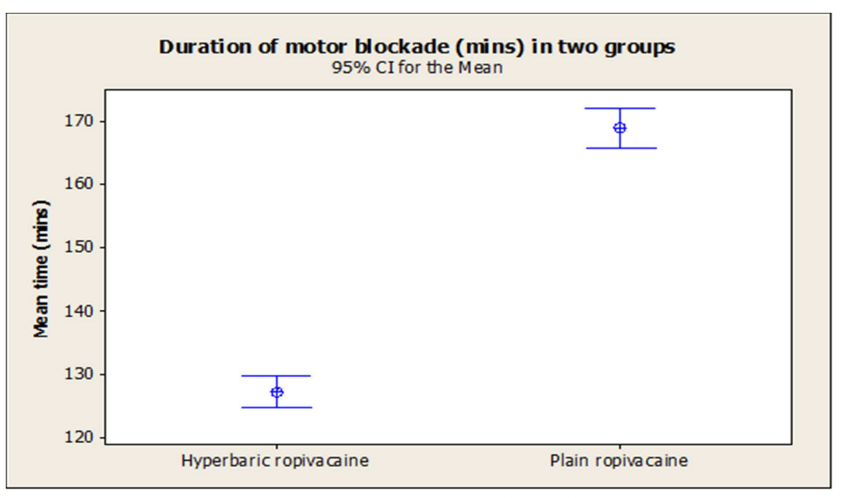

Figure 4: Duration of motor blockade (mins) in two groups

In group $\mathrm{H}$, mean duration of motor blockade was $127.33 \pm$ 6.53 mins, whereas in group $\mathrm{P}$, mean duration of motor blockade was $168.83 \pm 8.27$. The difference between the groups was statistically highly significant $(\mathrm{P}<0.001)$. Hence, showing that there was early recovery from motor block in group $\mathrm{H}$.

Table 2: Comparison between hyperbaric and plain ropivaciane in different parameters

\begin{tabular}{|c|c|c|c|c|c|c|}
\hline Variable & $\begin{array}{l}\text { hyperb } \\
\text { aric } \\
\text { ropivac } \\
\text { aine }\end{array}$ & $\begin{array}{l}\text { plain } \\
\text { ropivac } \\
\text { aine }\end{array}$ & $\begin{array}{l}\text { Mean } \\
\text { differe } \\
\text { nce }\end{array}$ & $\begin{array}{l}95 \% \\
\text { CI of } \\
\text { differe } \\
\text { nce }\end{array}$ & $\begin{array}{l}\text { t- } \\
\text { val } \\
\text { ue }\end{array}$ & $\begin{array}{l}\text { p- } \\
\text { value }\end{array}$ \\
\hline $\begin{array}{l}\text { Time of } \\
\text { onset of } \\
\text { sensory } \\
\text { block at } \\
\text { t10 }(\mathrm{sec})\end{array}$ & $\begin{array}{l}257.5 \pm \\
23.03\end{array}$ & $\begin{array}{l}478.0 \pm \\
16.48\end{array}$ & 220.50 & $\begin{array}{l}210.15 \\
- \\
230.85\end{array}$ & $\begin{array}{l}42.6 \\
4\end{array}$ & $\begin{array}{l}\mathrm{P}<0.0 \\
001\end{array}$ \\
\hline $\begin{array}{l}\begin{array}{l}\text { Duration } \\
\text { of } \\
\text { sensory } \\
\text { blockade( } \\
\text { min) }\end{array} \\
\end{array}$ & $\begin{array}{l}201.7 \pm \\
8.64\end{array}$ & $\begin{array}{l}261.17 \pm \\
8.27\end{array}$ & 59.50 & $\begin{array}{l}55.13- \\
63.87\end{array}$ & $\begin{array}{l}27.2 \\
4\end{array}$ & $\begin{array}{l}\mathrm{P}<0.0 \\
001\end{array}$ \\
\hline $\begin{array}{l}\text { Time of } \\
\text { onset of } \\
\text { motor } \\
\text { blockade( } \\
\text { sec) }\end{array}$ & $\begin{array}{l}355.50 \pm \\
16.83\end{array}$ & $\begin{array}{l}568.33 \pm \\
2.76\end{array}$ & 212.83 & $\begin{array}{l}202.49 \\
- \\
223.18\end{array}$ & $\begin{array}{l}41.1 \\
8\end{array}$ & $\begin{array}{l}\mathrm{P}<0.0 \\
001\end{array}$ \\
\hline $\begin{array}{l}\text { Duration } \\
\text { of motor } \\
\text { blockade( } \\
\text { min) }\end{array}$ & $\begin{array}{l}126.33 \pm \\
5.71\end{array}$ & $\begin{array}{l}168.83 \pm \\
8.27\end{array}$ & 42.50 & $\begin{array}{l}38.83- \\
46.17\end{array}$ & $\begin{array}{l}23.1 \\
55\end{array}$ & $\begin{array}{l}\mathrm{P}<0.0 \\
001\end{array}$ \\
\hline
\end{tabular}

Onset of sensory and motor block is faster in group $\mathrm{H}$ compared to group $\mathrm{P}$, and also speed of recovery from sensory and motor block is faster in group $\mathrm{H}$ compared to group P.

\section{Discussion}

In our study, we noted that mean time for onset of sensory block at T10 was $257.5 \pm 23.03 \mathrm{sec}(4.2 \mathrm{~min})$ with $15 \mathrm{mg}$ of hyperbaric ropivacaine and $478.0 \pm 16.48 \mathrm{sec}(8 \mathrm{~min})$ with $15 \mathrm{mg}$ plain ropivacaine which was statistically highly significant $(\mathrm{P}<0.001)$. This shows that there is early onset of sensory block at T10 when ropivacaine is made hyperbaric by addintion of glucose.

Our findings are in affirmation with the study conducted by P. D. W. Fettes 5 and colleagues in which Forty patients undergoing elective perineal surgery were randomized to receive $3 \mathrm{ml}$ ropivacaine $5 \mathrm{mg} \mathrm{ml}-1$, either in plain solution or with glucose $50 \mathrm{mg} \mathrm{ml}-1$ intrathecally, and found that median time to onset of sensory block at T10 was 10 minutes with plain ropivacaine and $5 \mathrm{~min}$ with hyperbaric ropivacaine.

Our findings are also similar with study conducted by Kallio $\mathrm{H} 6$ and colleagues in which 56 patients undergoing surgery for lower extremities received intrathecally either $1.5 \mathrm{ml}$ of ropivacaine $10 \mathrm{mg} \mathrm{ml} \mathrm{(-1)} \mathrm{and} 0.5 \mathrm{ml}$ of glucose $300 \mathrm{mg} \mathrm{ml}(-$ 1) (HYP) or $2 \mathrm{ml}$ of ropivacaine $7.5 \mathrm{mg} \mathrm{ml}(-1)$ (PL) and found that the time for the onset of sensory block at T10 is 5 minutes with hyperbaric ropivacaine and 10 minutes with plain ropivacaine.

In all these studies onset of sensory block at T10 for plain ropivacaine is 10 minutes (range 5 to 40 minutes) and 5 minutes(range 5 to $20 \mathrm{~min}$ ) for hyperbaric ropivacaine, in our study we found that onset of sensory block at T10 is $478.0 \pm$ $16.48 \mathrm{sec}(8 \mathrm{~min})$ for plain ropivacaine and $257.5 \pm 23.03$ $\mathrm{sec}(4.2 \mathrm{~min})$ for hyperbaric ropivacaine almost comparable onset of sensory blockade. Our study is in affirmation with other similar studies that addition of glucose to plain ropivacaine increases the speed of onset of sensory block at T10.

P. D. W. Fettes, ${ }^{[5]}$ and colleagues noted that median maximum extent of sensory block with plain ropivacaine was T8 and hyperbaric ropivacaine was T4. Kallio $\mathrm{H}^{[6]}$ and colleagues noted that all patients in group hyperbaric achieved T (10) dermatome analgesia but only 64\% of Group Plain ropivacaine achieved T10 analgesia level. Essam A, ${ }^{[7]}$ and colleagues found that median maximum extent of sensory block is T8 for plain ropivacaine and T6 for hyperbaric ropivacaine. In our study we found median maximum extent of sensory block at T10 for plain ropivacaine and T6 for hyperbaric ropivacaine. These difference may be attributed to varying concentrations and volumes of the drug used in each studies. In conclusion in all studies it was found that addition of glucose to plain solution of ropivacaine increases the median maximum extent of sensory blockade.

Kallio, ${ }^{[6]}$ and colleagues noted that time of regression of block to $\mathrm{S} 1$ was longer $(270 \mathrm{~min})$ with plain ropivacaine when compared to hyperbaric ropivacaine group (210 $\mathrm{min})$. We also observed that regression of block to S1with 
hyperbaric ropivacaine $(201 \mathrm{~min})$ was faster compared to plain ropivacaine $(261 \mathrm{~min})$. This is in agreement with the above mentioned study and also study conducted by Fettes 5 and colleagues.

Fettes, ${ }^{[5]}$ and colleagues found that the onset of motor block was earlier in hyperbaric ropivacaine compared to plain ropivacaine. We also noticed that the mean time for onset of motor blockade was faster in hyperbaric ropivacaine( 355 sec) compared to plain ropivacaine $(568 \mathrm{sec})$. In studies of Khaw, ${ }^{[8]}$ and Kallio, ${ }^{[6]}$ they compared plain ropivacaine versus hyperbaric ropivaciane and found that onset of motor block is faster in hyperbaric group.

Fettes, ${ }^{[5]}$ and colleagues noted that duration of motor blockade was shorter in hyperbaric ropivacaine group (120 $\mathrm{min})$ compared to plain ropivacaine group (180 $\mathrm{min})$. We observed a shorter duration of motor blockade with hyperbaric ropivacaine (126 $\mathrm{min})$ compared to plain ropivacaine (168 $\mathrm{min})$. This is in agreement with the above mentioned study and also study conducted by Kallio, ${ }^{[6]}$ Essam, ${ }^{[7]}$ and colleagues, who also found shorter duration of motor blockade with hyperbaric ropivacaine when compared to plain ropivacaine. ${ }^{[9,10]}$

\section{Conclusion}

Our study reveals that $3 \mathrm{ml}$ of intrathecal $0.5 \%$ of hyperbaric ropivacaine ( $2 \mathrm{ml}$ of $0.75 \%$ plain ropivacaine and $1 \mathrm{ml}$ of $25 \%$ dextrose) produced more predictable and reliable sensory and motor block, with faster onset, than a $3 \mathrm{ml}$ of injection $0.5 \%$ plain ropivacaine $(2 \mathrm{ml}$ of $0.75 \%$ plain ropivacaine and $1 \mathrm{ml}$ of $0.9 \%$ normal saline) . Recovery from both sensory and motor block was early in hyperbaric ropivacaine compared to plain ropivacaine . Patients therefore mobilized more quickly after spinal anaesthesia with hyperbaric ropivacaine, something that may be particularly useful for ambulatory surgery and any operation when a long duration of block is unnecessary or undesirable. Plain solutions of ropivacaine are associated with a less favourable pattern of block such that we advocate that they should not be used for surgery at or above the dermatomal level of the T10.

\section{References}

1. Margaret Wood, Alastair JJ Wood, Drugs and Anesthesia, Pharmacology for Anesthesiologists, 2nd Ed. Williams and Wilkins Ltd., 1990; 319- 342.

2. Robert k Stoelting, Pharmacology and Physiology in Anaesthetic Practice, 3rd Ed. Lippincot Raven, 1999. p 158-79.

3. Camorcia, Michela, Capogna, Giorgio Columb, Malachy et al. 2005 "Minimum Local Analgesic Doses of Ropivacaine, Levobupivacaine, and Bupivacaine for Intrathecal Labor Analgesia": Anesthesiology. 102:646-50.

4. Ekenstam B, Egner B, Petterson G. 1957 "Local anaesthetic I.N-alkyl pyrrolidine and N- alkyl piperidine carboxylic acid amides": Acta Chem Scand. 11:1183-90.

5. P. D. W. Fettes, G. Hocking, M. K. Peterson et al 2005. "Comparison of plain and hyperbaric solutions of ropivacaine for spinal anaesthesia": $\mathrm{Br}$ J Anaesth 2005; 94: 107-11.

6. Kallio H, Snall EV, Tuomas CA, Rosenberg PH,2004“Comparison of hyperbaric and plain ropivacaine $15 \mathrm{mg}$ in spinal anaesthesia for lower limb surgery.’Br J Anaesth 2004 Nov;93(5):664-9.

7. Essam A. Eid MD, Faisal AlSaif. FRCS, AB,2007 "Plain Versus Hyperbaric Ropivacaine for Spinal Anesthesia in Cirrhotic Patients Undergoing Ano-rectal Surgery."AJAIC 2007 March;vol 10 No 1.

8. Khaw KS, Nagan Kee WD, Wong M, Lee A. 2002 "Spinal ropivacaine for cesarean delivery: A comparison of hyperbaric and plain solutions": Anaesth Analg.94:680-5.

9. Gautier PE, De Kock M, Van Steenberge A, Poth $\mathrm{N}$ et al,1999“Intrathecal Ropivacaine for Ambulatory Surgery: A Comparison Between Intrathecal Bupivacaine and Intrathecal Ropivacaine for Knee Arthroscopy.”:Anesthesiology 1999 Nov;91(5):1239-45.

10. McDonald SB, Liu SS, Kopacz DJ, Stephenson CA 1999 "Hyperbaric Spinal ropivacaine: a comparison to bupivacaine In volunteers.”Anesthesiology.1999 APR;90(4):971-7.

Copyright: ( ) the author(s), publisher. Academia Anesthesiologica International is an Official Publication of "Society for Health Care \& Research Development". It is an open-access article distributed under the terms of the Creative Commons Attribution Non-Commercial License, which permits unrestricted non-commercial use, distribution, and reproduction in any medium, provided the original work is properly cited.

How to cite this article: Waris I, Khan KDI. A Comparative Study of Plain and Hyperbaric Solution of Ropivacaine for Spinal Anaesthesia in Minor Gynaecological and Urological Surgeries. Acad. Anesthesiol. Int. 2019;4(2):44-47.

DOI: dx.doi.org/10.21276/aan.2019.4.2.11

Source of Support: Nil, Conflict of Interest: None declared. 